\title{
A study of alcohol use pattern among married men in rural Tamil Nadu, India - policy implications
}

\author{
V. Thirumagal ${ }^{1}$,K. Shanmuga Velayutham ${ }^{2}$, Samiran Panda ${ }^{3}$. \\ ${ }^{I}$ TT Ranganathan Clinical Research Foundation (TTK Hospital), Chennai, \\ India; ${ }^{2}$ Department of Social Work, Loyola College, Chennai, India; \\ ${ }^{3}$ Indian Council of Medical Research, Kolkata, India. \\ Correspondence email: thirumagalv@gmail.com
}

\begin{abstract}
Alcohol consumption pattern in India varies remarkably from many other countries. In India, most men are abstainers (70\% to $90 \%)$ while less than $2 \%$ of women use alcohol. However, the men who use alcohol tend to drink at hazardous levels. This study examines alcohol use pattern among married men in rural sites spreading across five districts in the State of Tamil Nadu in South India. The type, frequency and quantity of alcohol consumed in the past one year were examined and all alcohol users were screened using Fast Alcohol Screening Test (FAST).Out of the 1626 men interviewed, 61.25\% (996) had not used alcohol in the past one year and 8.49\% (138) were identified as problem drinkers based on FAST. In terms of the quantity consumed, $37.26 \%$ of the alcohol users $(234 / 628)$ drank five units or more in a typical drinking day indicating heavy alcohol use. The significantly higher level of problem drinkers in one of the five study sites indicated that easy access to cheap liquor can lead to heavy alcohol use. Pattern of alcohol use was also examined in terms of education and occupation as indicators of socio-economic status. There was a high degree of concordance between the wife's reports of the spouse's alcohol use frequency. Focus group discussions were also carried out in the community to examine community's perception of alcohol use patterns. The study findings are examined in terms of the availability theory related to alcohol use and the Social Determinants Theory (SDT).
\end{abstract}




\section{دراسة نمط تعاطي الكحول بين الرجال المتزوجين في المناطق الريفية لولاية تاميلنادو بالهند الوقع على

$$
\text { تيروماجال في. و شانموجا فيلايوتام ك. و باندا س. }
$$

الملخص: تختلف سيمات تعاطي الكحول في الهند بشكل كبير مقارنة بدول أخرى. فتجد معظم الرجال في

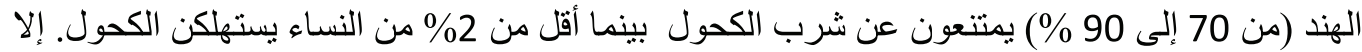

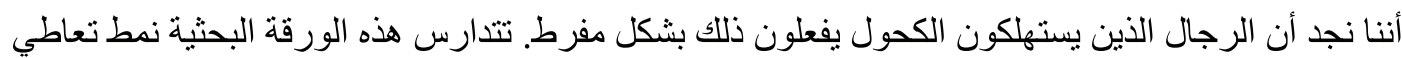

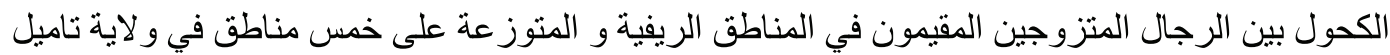

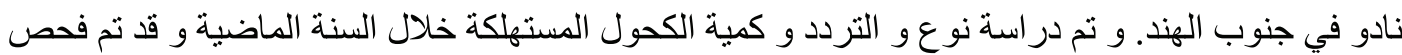

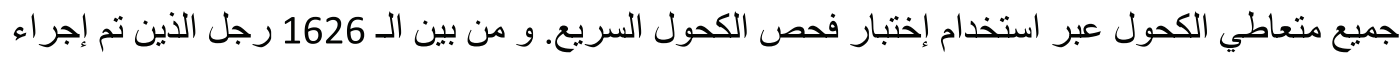
حوار معهم 61,21\% (996) لم يستهلكوا الكحول خلال السنة الماضية و 8,49\% (138) تم تصنيفهر

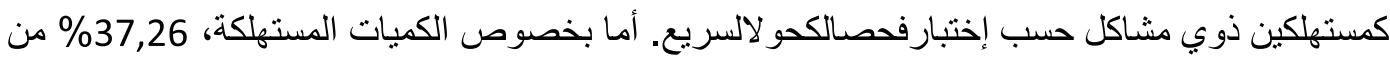

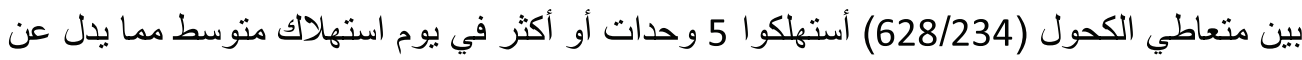

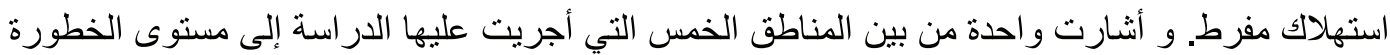

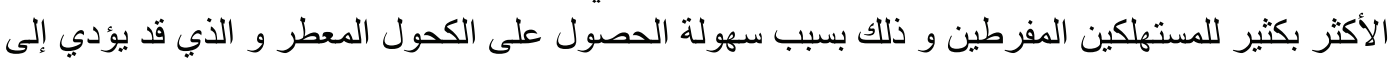

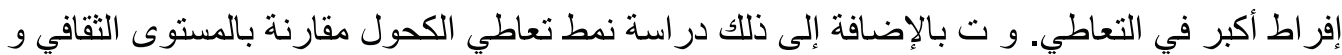

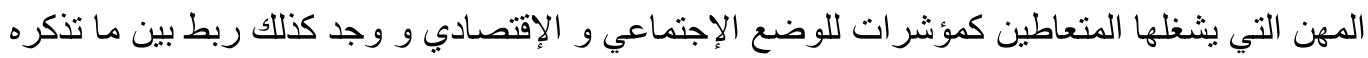

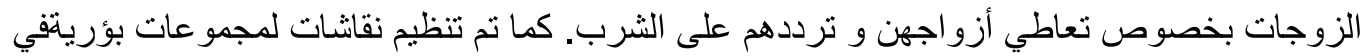

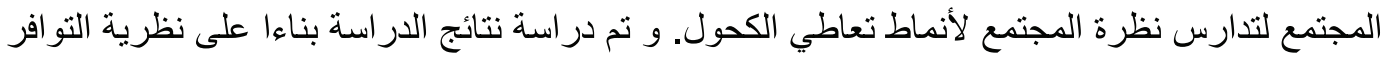
المتعلقة بتعاطي الكحول و نظرية المحددات الإجتماعية.

Keywords: Alcohol use in rural India, Alcohol price

\section{Introduction}

There is much harm in alcohol use which is a cause of concern in many parts of the world and mostly in India. In India where nearly half of alcohol consumed is undocumented, sales of alcohol which is recorded has increased by nearly three times between 2000 and $2009 .{ }^{1}$ With economic development and globalisation of the world market, alcohol consumption is expected to rise and eventually increase the incidence of alcohol related health and social problems. Examining variables associated with heavy alcohol use within a community can guide policy development related to alcohol availability and sale.

India is generally considered a 'dry' nation and studies have repeatedly shown that India has a large population of alcohol abstainers. The National 
Household Survey on Drug Abuse in India (2001), reported that $74.1 \%$ of males were life time alcohol abstainers and $21.4 \%$ had used alcohol during the previous month. It was estimated that India had 62.46 million alcohol users while roughly only one sixth (11.08 million) used drugs other than alcohol. ${ }^{2}$ The National Family Health Survey - 3 (NFHS 3) showed that 32\% of men aged between 15 to 54 years consume alcohol while in the case of women it is only $2 \%{ }^{3}$

Despite the fact that a large proportion of the Indian populace are abstainers, the pattern of alcohol consumption among those who drink is worrying. Research has shown that more than $50 \%$ of alcohol consumers satisfy the criteria for hazardous drinking in India. ${ }^{1}$ Benegal commented that the "signature pattern in India was one of heavy drinking wherein more than five drinks are consumed on a typical occasion". ${ }^{4}$ Indian studies have also highlighted the preference for use of distilled spirits with a higher percentage of alcohol than wine or beer. Alcohol sales figures in Tamil Nadu show that production of distilled spirits was about 100 million litres than beer. ${ }^{5}$

The 2011 NIMHANS report highlights that alcohol use is more prevalent among the educationally deprived populations. Analysing household expenditure, a Government report showed that regular alcohol use was more among those below the poverty line $(5.9 \%)$ when compared to others $(3.9 \%)$ with a ratio of $1.5 .{ }^{1}$ Another study showed that while $12 \%$ of men in the lowest wealth quintile drank almost daily, only $6 \%$ of men in the highest wealth quintile did the same. ${ }^{3}$

Examining alcohol availability and use in a rural area in Tamil Nadu, John et al surmised that use of Indian-made foreign liquor (distilled spirits) and living in a village which brewed illicit alcohol increased the risk for hazardous use. ${ }^{6}$ This indicated that easy access to cheap and strong liquor facilitates the increased risk related to alcohol use.

Each Indian state has its own set of rules regarding alcohol sale and most states generate an income of $15 \%-20 \%$ of its total state revenue from the sale of alcohol. ${ }^{1}$ In Tamil Nadu, the state where the present study was conducted, $13.6 \%$ of the total state revenue was generated through the sale of alcohol in 2006 2007. In a landmark policy change in 2003, the Tamil Nadu Government took over the retail sales of alcohol. Through a series of measures, illicit alcohol trade was wiped out to a large extent and Government-run shops (TASMAC) were the only sale outlets, apart from a few high end bars and hotels. An increase of $40.34 \%$ in turnover was noted and additional revenue of Rs. 15.64 billion was generated in the first 11 months when retail alcohol sales were taken over by the Government. ${ }^{5}$ In this scenario, the present study was undertaken in 2007 to describe alcohol use prevalence across the five sites in the rural areas of Tamil Nadu. Alcohol use pattern was examined in relation to socio econom- 
ic variables such as education and occupation. Focus group discussions were conducted with men and women in the villages to discuss observations related to alcohol use.

Tamil Nadu, one of the 28 states in India, is divided into 30 districts and these are further divided into taluks, panchayats, villages and hamlets. The study was conducted in 10 hamlets with two adjoining hamlets situated in five different districts in Tamil Nadu.

\section{Figure 1. The location of the study sites}

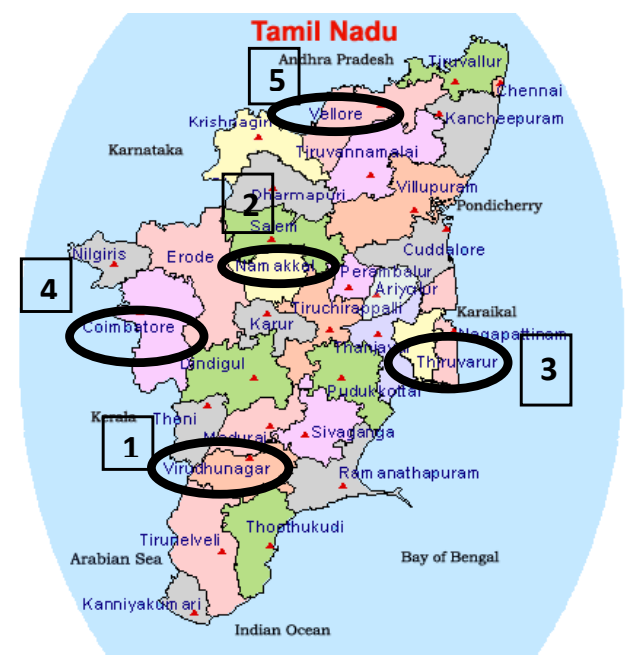

Site 1: Virudhunagar district

Site 4: Coimbatore district

Site 2: Nammakal district

Site 5: Vellore district

Site 3: Thiruvarur district

\section{Methods}

Using Government records maintained in each village, names of married couples (where the husband was aged 55 or less) were listed in each hamlet. Door to door visits were made to interview the husband and wife separately. The purpose of the study was explained, confidentiality assured and verbal consent was sought from respondents to participate in the research. Couples whose names were not in the list but who lived in the village and met the inclusion criteria were also interviewed during door to door visits. Male interviewers met the husband while female interviewers collected information from the wife. Table 1 presents information related to the sample covered in each site. 
Table 1. Number of married couples per village records and coverage

\begin{tabular}{|l|c|c|c|c|}
\hline Site & $\begin{array}{c}\text { No. of couples as per } \\
\text { record in each hamlet }\end{array}$ & $\begin{array}{c}\text { No. of couples } \\
\text { covered }\end{array}$ & $\begin{array}{c}\text { No. of } \\
\text { refusals }\end{array}$ & $\begin{array}{c}\text { Percentage } \\
\text { covered }\end{array}$ \\
\hline Site 1 & 670 & 240 & 70 & $35.82 \%$ \\
& 450 & 253 & 50 & $56.22 \%$ \\
\hline Site 2 & 399 & 202 & 25 & $50.63 \%$ \\
& 206 & 116 & 10 & $56.31 \%$ \\
\hline Site 3 & 89 & 109 & 1 & $122.47 \%$ \\
& 63 & 83 & 2 & $131.75 \%$ \\
\hline Site 4 & 168 & 127 & 4 & $75.59 \%$ \\
& 228 & 255 & 4 & $94.4 \%$ \\
\hline Site 5 & 270 & 118 & 6 & $124.21 \%$ \\
\hline
\end{tabular}

Two questionnaires were developed with 14 structured questions in each, directed at men and women. Both questionnaires elicited basic demographic data as well as information about alcohol use. Women were asked about their own alcohol consumption as well as their perception on the husband's drinking frequency. Men were asked about the type, quantity and frequency of their alcohol consumption. FAST was applied to the men who had used alcohol in the past one year. FAST is a four stepped screening test for the detection of hazardous drinking with $91 \%$ sensitivity and $95 \%$ specificity in comparison with AUDIT as the golden standard when used in a primary care setting. ${ }^{7}$ Persons who scored three or more in FAST were identified as Problem Drinkers (PD) and those who used alcohol in the past years but scored two or less in FAST were treated as Controlled Drinkers (CD). Those who did not use alcohol in the past one year were considered as Non Drinkers (ND).

Focus Group Discussions (FGD) were also carried out. Caste-based identification is a reality in all the study sites and some castes were considered superior. Each group lived in clusters in a specific geographical location in the village. To ensure a balanced view, 20 FGDs were conducted with men and women as well as people from both castes to ensure gender and caste balance. 


\section{Results}

Mean age of men was 39.21 years (age range 19 to 55) and women's mean age was 33.2 years (age range 18 to 55). Literacy level of men was $76.1 \%$ (1238 of 1626) while that of their wives was $62.1 \%$ (1010 of 1626). Unemployment level of men was $1.8 \%$ while that of women was $44.8 \%$.

Almost all women and a considerable number of married men $(61.38 \%$, 998/1626) below the age of 55 years did not consume alcohol over the past one year. Only $1.17 \%(19 / 1626)$ of the married women covered in the survey had consumed alcohol in their lives. In $79.7 \%$ of the couples, the wife's perception of husband's drinking frequency corroborated with the self reports of the husband. Distilled spirits (brandy or arrack) were the most preferred beverage while occasional consumption of beer or toddy was reported from two sites. Table 2 highlights the FGD excerpts.

\section{Table 2. FGD excerpts about preferred alcoholic beverages- comparison between sites}

\begin{tabular}{|l|l|}
\hline FGD excerpts from Sites 1 to 4 & FGD excerpts from Site 5 \\
$\begin{array}{l}\text { Site 1: Arrack is not available here. Whisky \& } \\
\text { brandy are bought from TASMAC*. }\end{array}$ & $\begin{array}{l}\text { - Most people drink only ar- } \\
\text { rack. Only 1-2 drink brandy. }\end{array}$ \\
$\begin{array}{l}\text { Site 2: No arrack. Only TASMAC (outlet liquor) } \\
\text { is available (Brandy, whisky or beer only). Oth- } \\
\text { er than beer, they all drink hard liquor (distilled } \\
\text { spirits) only }\end{array}$ & $\begin{array}{l}\text { - Andhra border is only 3km } \\
\text { away. Arrack is sold at the } \\
\text { border. Close to the border } \\
\text { arrack is sold at Rs.10/. Just } \\
15 \mathrm{~km} \text { away from the border it } \\
\text { costs Rs.5/ }\end{array}$ \\
$\begin{array}{l}\text { Site 3: Arrack is not manufactured here. There- } \\
\text { fore, brandy is popular. Arrack is found in Karaik- } \\
\text { kal about 60 km from here. }\end{array}$ & $\begin{array}{l}\text { - Can the guy who buys arrack } \\
\text { at Rs. 10/, afford brandy at } \\
\text { Site 4: Arrack is not available. Therefore, toddy } \\
\text { and brandy is popular - most drink brandy. Toddy } \\
\text { is found about 40km away in Kerala }\end{array}$ \\
\hline
\end{tabular}

\footnotetext{
* TASMAC - Government owned retail sales outlet
}

Commenting on the pattern of alcohol consumption in the earlier years when illicit liqour was available, an FGD participant commented, "Previously when arrack was available at a low price people drank more. You need at least Rs.100/- to buy liquor. If he worries about the Rs.100/-, his intoxication level reduces."

Previously, one could get drunk with four glasses of arrack which will cost him Rs. 10/- 
Now it costs Rs.65/-, therefore people don't drink as much" (Site 3: male, 31 years, lorry owner, resident for 13 years)". Another said, "Previously when arrack was available people drank on a daily basis" (Site 2: woman, 41 years, tailor, resident for 25 years). FGD excerpts such as those cited above indicate that scarcity of low cost alcohol influenced consumption patterns.

The number of NDs, CDs and PDs in each site as well as distribution in terms of quantity and frequency of alcohol consumption across the five sites presented in Table 2.

Table 3. Alcohol use pattern among men across the five rural sites

\begin{tabular}{|c|c|c|c|c|c|c|c|}
\hline \multirow[t]{3}{*}{$\begin{array}{l}\text { Site } \\
\text { \& no. } \\
\text { of men }\end{array}$} & \multirow{3}{*}{$\begin{array}{l}\text { No. of } \\
\text { NDs }\end{array}$} & \multicolumn{2}{|c|}{$\begin{array}{l}\text { No. of alcohol using } \\
\text { in men and percent- } \\
\text { age } \\
(n=628)\end{array}$} & \multicolumn{4}{|c|}{$\begin{array}{l}\text { Frequency and quantity of alcohol use* } \\
(n=628)\end{array}$} \\
\hline & & \multirow{2}{*}{$\begin{array}{l}\text { Con- } \\
\text { tro-Iled } \\
\text { drinkers } \\
\text { (CD) }\end{array}$} & \multirow{2}{*}{$\begin{array}{l}\text { Problem } \\
\text { drinkers } \\
\text { (PD) }\end{array}$} & \multicolumn{2}{|c|}{ Small quantity } & \multicolumn{2}{|c|}{ Large quantity } \\
\hline & & & & $\begin{array}{l}\text { less fre- } \\
\text { quent }\end{array}$ & $\begin{array}{l}\text { more } \\
\text { frequent }\end{array}$ & $\begin{array}{l}\text { less fre- } \\
\text { quent }\end{array}$ & $\begin{array}{l}\text { more } \\
\text { frequent }\end{array}$ \\
\hline $\begin{array}{l}\text { Site } 1 \\
493\end{array}$ & $\begin{array}{l}225 \\
(45.64 \%) \\
\end{array}$ & $\begin{array}{l}237 \\
(48.07 \%)\end{array}$ & $\begin{array}{l}31 \\
(6.29 \%) \\
\end{array}$ & $\begin{array}{l}184 \\
(68.66 \%)\end{array}$ & $\begin{array}{l}52 \\
(19.40 \%)\end{array}$ & $\begin{array}{l}15 \\
(5.60 \%)\end{array}$ & $\begin{array}{l}17 \\
(6.34 \%)\end{array}$ \\
\hline $\begin{array}{l}\text { Site } 2 \\
318\end{array}$ & $\begin{array}{l}217 \\
(68.24 \%)\end{array}$ & $\begin{array}{l}87 \\
(27.35 \%)\end{array}$ & $\begin{array}{l}14 \\
(4.40 \%)\end{array}$ & $\begin{array}{l}38 \\
(37.62 \%)\end{array}$ & $\begin{array}{l}7 \\
(6.93 \%)\end{array}$ & $\begin{array}{l}46 \\
(45.54 \%)\end{array}$ & $\begin{array}{l}10 \\
(9.9 \%)\end{array}$ \\
\hline $\begin{array}{l}\text { Site } 3 \\
192\end{array}$ & $\begin{array}{l}124 \\
(64.58 \%)\end{array}$ & $\begin{array}{l}53 \\
(27.60 \%)\end{array}$ & $\begin{array}{l}15 \\
(7.81 \%)\end{array}$ & $\begin{array}{l}29 \\
(42.65 \%)\end{array}$ & $\begin{array}{l}26 \\
(38.24 \%)\end{array}$ & $\begin{array}{l}5 \\
(7.35 \%)\end{array}$ & $\begin{array}{l}8 \\
(11.76 \%)\end{array}$ \\
\hline $\begin{array}{l}\text { Site } 4 \\
192\end{array}$ & $\begin{array}{l}164 \\
(65.6 \%)\end{array}$ & $\begin{array}{l}68 \\
(27.2 \%)\end{array}$ & $\begin{array}{l}18 \\
(7.2 \%)\end{array}$ & $\begin{array}{l}32 \\
(37.21 \%)\end{array}$ & $\begin{array}{l}1 \\
(1.16 \%)\end{array}$ & $\begin{array}{l}49 \\
(56.98 \%)\end{array}$ & $\begin{array}{l}4 \\
(4.65 \%)\end{array}$ \\
\hline $\begin{array}{l}\text { Site } 5 \\
373\end{array}$ & $\begin{array}{l}268 \\
(71.85 \%) \\
\end{array}$ & $\begin{array}{l}45 \\
(12.06 \%)\end{array}$ & $\begin{array}{l}60 \\
(16.09 \%) \\
\end{array}$ & $\begin{array}{l}44 \\
(41.90 \%)\end{array}$ & $\begin{array}{l}2 \\
(1.90 \%)\end{array}$ & $\begin{array}{l}28 \\
(26.67 \%)\end{array}$ & $\begin{array}{l}31 \\
(29.52 \%)\end{array}$ \\
\hline $\begin{array}{l}\text { Total } \\
1626\end{array}$ & $\begin{array}{l}998 \\
(61.38 \%)\end{array}$ & $\begin{array}{l}490 \\
(30.15 \%)\end{array}$ & $\begin{array}{l}138 \\
(8.49 \%)\end{array}$ & $\begin{array}{l}327 \\
(52.07 \%)\end{array}$ & $\begin{array}{l}67 \\
(10.67 \%)\end{array}$ & $\begin{array}{l}164 \\
(26.11 \%)\end{array}$ & $\begin{array}{l}70 \\
(11.15 \%)\end{array}$ \\
\hline
\end{tabular}

$*$ Small quantity $=1-4$ units; large quantity $=5$ units or more $(30 \mathrm{ml}$ of spirits $=1$ unit, $100 \mathrm{ml}$ arrack $=5$ units)

$*$ Less frequently $=$ Once a week or less frequently; More frequently $=$ Twice a week or more often 
Alcohol consumption level was examined in relation to the level of education and occupation. Problem alcohol users were less likely to be literate when compared to non-alcohol users and controlled drinkers ( $\mathrm{pd}<\mathrm{nd}$, OR $=0.47,0.31$ to 0.69 , $\mathrm{p}=0.00 ; \mathrm{pd}<\mathrm{cd}, \mathrm{OR}=0.64,0.42$ to $0.98, \mathrm{p}=0.03)$. The mean age of schooling of non-consumers of alcohol (7.04 years, $\sigma=4.84)$ was significantly higher than that of alcohol consumers $(4.94, \sigma=4.10)$ with $\mathrm{z}$ test showing a significant difference at 0.01 level.

When comparing consumption with occupation type, problem drinkers were three times more likely to be working as labourers $(\mathrm{OR}=3,1.8$ to 5.2 , $\mathrm{p}=<0.01)$ than other occupations.

A higher percentage of PD $(45.65 \%, 63 / 138)$ reported presence of health problems when compared to CD (29.84\%) and ND (29.2\%). Problem drinkers were twice as likely to report health problems when compared to CD and ND (pd: $c d, O R=2,95 \%$ CI, 1.3 to $3, p=<0.01$ and $p d: n d, O R=2.1,95 \%$ CI, 1.5 to $3, \mathrm{p}=<0.01)$. Tobacco use was also higher among the problem alcohol users $(79.41 \%, 108 / 138)$ when compared to controlled drinkers $(62.17 \%)$ and non-alcohol users (34.31\%).

All the five study sites were in rural areas of Tamil Nadu and alcohol retail sales were managed by the Government. Yet, Site five presented a distinctively different high risk profile. Site five had the highest number of heavy and frequent alcohol consumers $(31 / 105,29.52 \%)$ as well as problem alcohol users $(60 / 373,16.09 \%)$.

\section{Discussion}

Quantity and frequency of drinking and problem drinking based on screening test FAST were two aspects examined in this study. Though more than half, 61.38\% (998/1626) of men abstained from alcohol; among those who drank 37.3\% (234/628) did so at harmful levels using five units or more on a typical drinking day. On the other hand, FAST identified 21.97\% (138/628) of alcohol users as PDs. This is in line with other Indian studies which reported that although a significant number of men abstain from alcohol, those who drink tend to consume alcohol at hazardous levels.

\section{Social vulnerability factors and problem alcohol use}

Alcohol use risk profile when examined in terms of socio economic indicators showed that PDs were more likely to be illiterate and when literate had fewer years of schooling and three times more likely to be employed as labourers when compared to other men in the community. PDs were more likely to use tobacco and twice as likely to report health problems which 
added to the health care costs of this socially marginalised group. These findings resonated with the social determinants of health theory which indicated that health problems including addiction is bound to be higher among groups in the lower social ranks of society. ${ }^{8}$

\section{Alcohol availability in community as risk factor for alcohol related problems}

Among the five sites where this study was undertaken, Site five stood out on two counts. Site five was situated close to the neighbouring state border (Figure 1) and the only site that had access to low cost arrack from across the border. While arrack was the preferred beverage in Site five, brandy purchased from Government-owned retail outlets were mostly consumed in the other four sites. In terms of cost, $180 \mathrm{ml}$ of brandy (with $42.8 \%$ of ethyl alcohol) costs Rs. 70/- in the four sites while the same quantity of arrack (with 50-60\% ethyl alcohol) cost Rs.20/- only.

Site five had the highest percentage $(29.52 \%)$ of heavy and frequent alcohol consumers compared to the range of $4.65 \%$ to $11.76 \%$ in the other four sites (Table 1). Based on FAST scores, alcohol users in Site five were nearly five to 10 times more likely to be PDs when compared to the other four sites $(\mathrm{p}=<0.01)$ (Site 1: $\mathrm{OR}=10.19,5.76<\mathrm{OR}>10.13$; Site 2: $\mathrm{OR}=8.29,3.99<\mathrm{OR}>17.46$, Site $3: \mathrm{OR}=4.71,0.24<\mathrm{OR}>10.01$, Site $4, \mathrm{OR}=5.042 .52<\mathrm{OR}>10.17)$. It is also important to note that Site five also had the highest number of men who did not use alcohol when compared to other sites.

Incidence of high risk drinking practices in Site five can be clearly attributed to easy access to low cost alcohol. Availability theory proposed by Stockwell and Gruenewald (2004) examines the impact of alcohol price on consumption levels; wherein price includes cost of alcohol as well as the cost of access. Alcohol consumption, as it has been demonstrated, behaves like any other commodity, the higher the price, lesser the demand and lesser the price, the higher the demand with higher levels of consumption leading to greater levels of harm. ${ }^{9}$

Reviewing effectiveness of alcohol policies implemented by various countries, increasing the alcohol sale price was presented as the most effective approach with research evidence of effectiveness. Moreover, the cost of implementation of such population based policies is low and ease of implementation is high making this option highly viable. ${ }^{10}$ Limiting the number of sales outlets, restrictions on the time of availability and ensuring price increase of alcohol in line with the inflation would also help.

In addition to ensuring controls over the sale of alcohol, other public health 
interventions are also required. Presence of a large alcohol abstinent population needs to be recognised as an inherent strength in the community. However, prevalence of hazardous drinking necessitates efforts to increase awareness about alcohol-related harm especially among the socially disadvantaged groups. Moreover, brief intervention services at primary health care settings need to be made available to identify and assist hazardous alcohol users. Considering that the poor sections of the society are affected the most, making the services available at the Government-owned health care units emerges as an urgent need.

Restricting alcohol related harm by ensuring higher alcohol cost has demonstrated effectiveness but some difficulties have been cited. Edwards et al discussed four concerns of which two are related to the situation in Tamil Nadu and discussed here. ${ }^{9}$ First of all, price increase on commercial beverages may increase illicit alcohol production. This was addressed by the Government of Tamil Nadu by coming down consistently and strongly on illicit alcohol production. With retails sales solely in the Government's control, the Government also had a vested interest, as illicit alcohol activities would divert customers and reduce the State revenue.

Secondly, such restrictions on availability will not work effectively if cross border purchase or imports continue from other communities which do not follow similar guidelines. The study findings corroborate this. Though Site five was governed by Tamil Nadu laws, it did not influence alcohol use patterns as low cost illicit alcohol was easily available in the neighbouring state. The absence of a National Alcohol Policy in India and the inability to launch an orchestrated response is brought into sharp focus here.

Easy availability of low cost alcoholic spirits is associated with increased alcohol consumption and higher prevalence of problem alcohol use. The study findings urge policy makers to restrict easy access to alcohol at low cost as it would lead to more hazardous alcohol use affecting the poor more than the other social classes. Launching efforts to increase awareness about alcohol and making available brief intervention services in primary health care settings is also highlighted. The need for developing a National Alcohol Policy to structure and implement efforts from the public health perspective is of course crucial and long overdue.

(This study was part of the doctoral research study undertaken by the first author) 


\section{References}

1. Gururaj G, Pratima Murthy, Girish N \& Benegal V. Alcohol related harm: Implications for public health and policy in India. Bangalore: NIMHANS, Publication No. 73, 2011, 11 to 16, 30.

2. Ray R, Mondal AB, Gupta K, Chatterjee A and Bajaj P. National survey on extent, pattern and trends of drug abuse in India. Delhi: Ministry of Social Justice and Empowerment and United Nations Office on Drugs and Crime ROSA, 2004, 19 to 21.

3. National Family Health Survey (2005 - 2006), International Institute of Population Sciences (IIPS) and Macro International, Mumbai, 2007, 429 to $431,342$.

4. Benegal V. India Alcohol and Public Health. Addiction, 2005, Vol.100. 1051 to 1056

5. Government of Tamil Nadu, Prohibition and Excise Department, Policy note 2006 - 2007, Demand No. 36 \& 37, downloaded from www. tn.gov.in/policynotes/archives/policy2005-2006/prohibition_excise. htm on 11th November 2007.

6. John A, Barman D, Bal G, Chandy J, Samuel J, Thokchom N, Joy P, Vijaykumar S et al, Hazardous alcohol use in rural southern India: Nature, prevalence and risk factor, Natl Med J India 2009; 22:123- 125.

7. Manual for the Fast Alcohol Screening Test (FAST): Fast screening for alcohol problems, Health Development Agency and University of Wales College of Medicine, London, 2002, 3 to 8.

8. World Health Organisation, Social determinants of health, Wilkinson R and Marmot R ed., 2003, downloaded http://www.euro.who. int/_data/assets/pdf_file/0005/98438/e81384.pdf, November 2007, 24 to 25 .

9. Controls on the Physical Availability of Alcohol, Stockwell T and Gruenewald P, In The Essential Handbook of Treatment and Prevention of Alcohol Problems Heather N and Stockwell T (ed.), Susex, John Wiley and Sons, 2004, 215, 209.

10. Report: Alcohol in Europe, Chapter 7: The effectiveness of alcohol policy downloaded from http://ec.europa.eu/health-eu/news_alcoholineurope_en.htm on 5th March 2007, 263. 